\title{
Democracy Disenchanted and Autocracy Glamorized in Korea
}

\author{
Doowon Suh $^{1}$ \\ ${ }^{1}$ Graduate School of International Studies, Korea University, South Korea \\ Correspondence: Doowon Suh, Graduate School of International Studies, Anam-dong, Sunbuk-ku, Seoul, Korea.
}

Received: July 6, 2015

Accepted: July 20, 2015

Available online: August 25, 2015

doi:10.11114/ijsss.v3i6.1051

URL: http://dx.doi.org/10.11114/ijsss.v3i6.1051

\begin{abstract}
Economic prosperity and equitable economic distribution under authoritarian political repression began to be upended in Korea in 1987: democratic freedom replaced autarchy with a gradual economic slowdown. The financial crisis in 1997 further increased poverty and job insecurity. Post-crisis government welfare reform policies were too cumbersome to prevent worsening poverty and polarization, and a growing share of the lower class was left unprotected and remained social outcasts. The inability of the democratic regime to deal with the economic recession and the financial crisis raised the level of public discontent with the democratic government's performance, reducing public support for democracy. The dwindling legitimacy of democracy obviously imperiled its consolidation and sustainability. Though still devoted to democracy in principle, Koreans were deeply disillusioned with it in practice and worryingly attracted to a non-democratic mode of governance. Rising disgruntlement led to nostalgia for Park Chung Hee's authoritarian leadership. The coexistence and parallel adoption of democratic principles and of attraction to authoritarian practice not only slowed democratic consolidation but also marred democratic legitimacy.
\end{abstract}

Keywords: Democracy, Inequality, Poverty, Polarization, Authoritarian Nostalgia, Korea

\section{Introduction}

The democratization in South Korea (Korea hereafter) that began in June 1987 when a long-lasting authoritarian regime was toppled by a massive, nationwide civilian uprising has been acclaimed as an emblematic case in the third-wave democratization that began in Southern Europe in 1974. According to one Korean political analyst, in "the rule of law, accountability, control corruption, freedom, responsiveness, governmental effectiveness, regulatory quality, and economic reform most political rights and civil liberties [in Korea] have upgraded to the level of advanced democracies" (Im, 2011:595). Korea's democratic advancement was also internationally endorsed. In 1993-2011, Freedom House placed Korea among a group of liberal democracies with an average rating of 2.0 (or higher below) on a scale from 1 (high) to 7 (low) (Shin, 2011). With such "miraculous" progress, not only had electoral politics become "the only possible political game in town" (Shin, Park, Hwang, \& Jang, 2003:266), but Korean democracy had become fully "consolidated in the maximalist sense" (Hahm, 2008:129).

These lofty appraisals of Korean democratization have recently, however, been eclipsed by less optimistic assessments of the prospects for democratic sustainability and legitimacy. Scholars of democracy have established several criteria for judging the level of democratic consolidation. One often-cited standard is Huntington's (1991a) conception of a "two-turnover test," which refers to the two rotations of power from a ruling to an opposition party after democratic transition. Korea satisfied this condition in the 2008 presidential election. Along with the institutional criteria such as Huntington's two-turnover test, the attitudinal and behavioral aspect of the public at large has begun to be incorporated into evaluations of country's level of democratic consolidation (Linz \& Stepan, 1996), which is essentially a measure of citizens' cultural transformation. In line with this logic, Diamond (1999) specifies that democracy can only be effective and stable if more than $70 \%$ of citizens consider it preferable and, at the same time, less than $15 \%$ of the population would opt for a nondemocratic alternative if a democratic government failed to meet their expectations and dealt ineffectively with imminent socioeconomic and political problems. In this respect, Chu et al. (2008) deplore that fewer than half of emerging democracies meet these standards, rendering third-wave democratization prone to "democratic recession" (Chu, Diamond, Nathan, \& Shin, 2009:155).

In this paper, I argue that Korean democratization is no different from other fledgling democracies, and that the potential for democratic backsliding is real because of the recent trends of increasing authoritarian nostalgia, a more conservative voting pattern, and growing discontent with the poor performance of a democratic government, thereby 
damaging support for and legitimacy of democratic governance. After analyzing the underlying causes of these phenomena, I conclude that to maintain democracy in Korea, the government must urgently devise effective measures to resolve this threat to democratic consolidation and quality.

Korean democracy may wane or wax in future depending on the efficacy of democratic regime performance - especially on the task of alleviating the unprecedented rapid expansion of socioeconomic inequality, insecurity, and poverty after the financial crisis in 1997. The parallel development of political democratization and neoliberal globalization characterizes the main structural transformation in Korea as it does in most other countries. The still nascent democratic government may not be blamed for inadequately handling a myriad of socioeconomic and political predicaments caused by neoliberal globalization. Yet the state is the primary agent responsible for all these issues and for preventing hard-won democratic development from being swamped by the formidable tide of neoliberal globalization. As Huntington (1991b:33) stresses, "Economic development makes democracy possible; political leadership makes it real."

\section{Authoritarian Economic Growth with Equity}

Korea is probably known better to the world for its successful industrialization in the post-WWII era than for its political democratization. Export-oriented and state-directed industrialization began in 1961 after a military coup led by Park Chung Hee. Socioeconomic conditions then had improved little since the total devastation wrought by the Korean War (1950-53). Before the industrialization drive under the Park regime (1961-79), average per capita income was merely $\$ 80$, more than $80 \%$ of government revenues were supported by U.S. aid, and society was in absolute poverty. By the end of the authoritarian period, however, in 1989, average per capita income had risen to $\$ 8,000$ (Feng, 2011).

A less well known but still significant economic change achieved during the authoritarian period-and related to the subsequent political democratization (discussed below) - was the reduction in income inequality. Interesting and paradoxical was the fact that the decrease in socioeconomic inequality in Korea (as well as in other East Asian NICs such as Taiwan and Singapore) was achieved with an export-oriented industrialization strategy, which in principle was much likely to result in greater inequality than the inward-looking strategy of import substitution that was adopted by most other developing countries, notably the Latin American states. In order to ensure the international competitiveness of domestically produced commodities in foreign markets, the authoritarian government maintained from the outset of industrialization a low-income policy whereby the state instantaneously intervened in industrial disputes and ruthlessly repressed any attempts at labor organization or mobilization that could thwart production or raise wages (Koo, 2001). Under this low income policy and the brutal suppression of working-class activism, wage gaps and inequality were expected to increase rather than decrease by class and occupation.

In fact, however, in tandem with economic growth of $9.2 \%$ in the $1960 \mathrm{~s}, 10.3 \%$ in the $1970 \mathrm{~s}$, and $8.6 \%$ in the $1980 \mathrm{~s}$ (Cho, Pak, \& Kang, 2012), the Gini coefficient index — an indicator of income inequality-dropped from 0.45 in 1960 to 0.31 in 1991 (Kim, Kwon, Lee, \& Yi, 2011). Korea's standard of living during the authoritarian period had not only improved but also become more equitable. This trend clearly countered the received wisdom of Kuznets's (1955) theory of the inverted U-shaped relationship between economic growth and income inequality in advanced industrial societies. What happened in Korea was the opposite. And in fact an increase in inequality roughly coincided with the political transition from the authoritarian regime to a civilian democratic government.

Kim et al. (2011) have recently provided a convincing explanation of why income inequality shrank despite an authoritarian drive to industrialize through export. According their explanation, the Park administration showed adroit political leadership by initiating an authoritarian welfare system that provided needed support to workers. Instead of monopolizing welfare management, the government delegated it to an alliance between the state, business and industry, and the voluntary sector. By creating and maintaining this "mixed" and effective governance- that coopted capitalists and voluntary groups to deliver a variety of welfare services and at the same time preempted workers' grievances-and suppressing their excessive demands, the Park government successfully fulfilled the seemingly impossible tasks of simultaneously relieving poverty, reducing inequality, and promoting economic growth: a success, Kim and his associates claim, unmatched by any other country in the 1960s and the 1970s. The authoritarian welfare system only offered benefits to regular employees, but this employment-based and occupation-related welfare system was well established and was later taken over by the democratic regime. Yet it proved to be no longer effective in coping with newly emerging socioeconomic ordeals provoked by the 1997 financial crisis and aggravated by neoliberal economic restructuring and labor market flexibilization in subsequent years. The paradigmatic growth of the equality model in Korea ended with the beginning of democratization in 1987 (Feng, 2011), spawning a new and (to Koreans) unfamiliar era of living in political freedom but under economic poverty and polarization. 


\section{Democratic Political Freedom with Socioeconomic Inequality}

Democratization is by nature multidimensional, multilevel, and multiphased, which means that democratization is completed when multiple relations-political, social, economic, and cultural-are equally democratized; these dimensions do not progress at the same pace; democratization usually happens sequentially, with the development of liberalization first, then democratic transition, and finally democratic consolidation (Shin, 2012). It is likely that completed constitutional and electoral democracy in Korea will not be accompanied by social, economic, and cultural democratization. The latter may trail the former; or the former might be accomplished at the expense of the latter.

Some neoliberal economists who underscore the self-sufficiency and self-regulation of markets claim that economic improvement through neoliberal reforms and the "installation and legitimation of democratic institutions" can be attained simultaneously in a mutually beneficial manner (Linz \& Stepan, 1996:29). This argument reflects more a hope than a reality. I hasten to add, however, that I am not insisting that inequality is complete anathema to democracy, or that the current neoliberal reforms will not bring any benefits to democratization (Huber \& Solt, 2004). As Tilly (2007:110) suggests, a "functioning democracy can both emerge and survive in the presence of massive material inequalities." Also, as Huntington (1997:5) aptly points out, "Democracy is incompatible with total economic equality." Based on comparative research on the relationship between neoliberal reform and democratization in Latin America, Weyland (2004) highlights two positive consequences of neoliberalization on democratization. First, opening a market to the world economy enhances the international pressure for preserving democracy. Second, neoliberal globalization alters the power configuration of contending forces and sometimes eliminates the potential for backlash against democratization by radical socialist or populist mobilization that might imperil ruling elites' basic interests. This situation might heighten the elites' perception of a threat to their power, thereby prompting their authoritarian involution. Weyland (2004:152) argues that neoliberalism is a double-edged sword for democratization because it strengthens its sustainability but degrades its quality: "politics poses real dilemmas and painful trade-offs."

Yet it seems likely, as I will argue, that neoliberal reforms have done more harm than good for democratization. A capitalist market is in principle anarchic and far from humanitarian. For a democracy, especially a nascent one, to be sustainable and consolidated, as Linz and Stepan (1996:21) note, "sociopolitically crafted and accepted norms, institutions, and regulations ... that mediate between the state and the market" must exist; otherwise, "policies [for] government-mandated public goods" (p. 22) cannot be generated because a capitalist market is basically indifferent to expanding inequality and worsening poverty. Thus the "institutionalization of a politically regulated market" (Linz \& Stepan, 1996:22) is necessary to forestall growing inequality and "the probability of backsliding from democracy to dictatorship" (Houle, 2009:591), and to relieve "the principal obstacle to democracy," i.e., poverty (Huntington, 1991b:31).

Unless market regulation is properly institutionalized and practiced, market-oriented economic reforms can be highly detrimental to democratization. As a counterproductive consequence of neoliberalism, a democratic government's accountability and responsiveness could dwindle. Growing dissatisfaction with government performance could lead to lower political participation due to increasing political apathy and antipathy, resulting in the limited exercise of popular sovereignty, making democracy less durable (Weyland, 2004). Among the many negative side effects of neoliberal reforms on democracy, widening income inequality and increasing poverty are particularly relevant in Korea.

Before the inauguration of the first civilian Kim Young Sam administration (1993-97), an invigorated civil society and empowered labor movements contributed to reducing inequality by raising working-class income (Shin, 2008). But the pursuit of a globalization project and the occurrence of the financial crisis during the Kim regime dramatically changed the landscape. The aftermath of the 1997 financial crisis was characterized by class polarization with the disintegration of the middle class, excessive inequality, and rising pauperization. Korea barely survived a state moratorium and stayed afloat through bailout financing of $\$ 57$ billion from the IMF in 1997- the largest sum ever lent to a near insolvent country. In return for the financial aid, the IMF requested that the Kim Dae Jung administration (1998-2002) implement prompt and austere neoliberal reforms, focused on flexibilizing the labor market because international financial institutions deemed its rigidity to be a prime cause of the crisis. Consequently, Korea immediately legalized layoffs, and the skyrocketing growth of non-regular workers drastically polarized class structure and disintegrated the middle class that was a main pillar of democracy. Two-thirds of the middle class were demoted to the working class while the remaining one-third moved upward (Im, 2011:592). After the crisis, the proportion of non-regular workers exceeded 50\% of the total employed (55.9\% in 2001) and never declined thereafter (Im, 2011), which caused some international economic organizations to worry that such an excessively flexible labor market would retard economic recovery and reform. Labor market flexibilization proceeded unevenly. A higher percentage of workers with lower skills and income became non-regular workers, and female workers were a prime target of layoffs and employment status adjustment (Shin, 2008). In a situation where the social security system was paltry and welfare services were mainly reliant on employment (Kim et al., 2011), employment was critical to workers' welfare. Though still lower than in other countries 
in Asia, North America, and Europe, the unemployment rate in Korea rose from 2.1\% in 1995 to $4.4 \%$ in 2000 after the financial crisis (Cho et al., 2012). The economic growth rate that had long remained at nearly $10 \%$ per year plummeted to $-5.7 \%$ in 1998 and only recovered to around 5\% in the $21^{\text {st }}$ century. The income gap between regular and non-regular workers widened astonishingly to the extent that the average wage of non-regular workers reached only half that of regular workers in 2005 (Kim, 2006).

Class polarization and labor market flexibilization inevitably led to the exacerbation of inequality. The Gini index soared from 0.283 before the financial crisis in 1997 to 0.319 in 2001 ( $\operatorname{Im}, 2011$ ), exceeding the average for Organization for Economic Cooperation and Development [OECD] countries (Kang 2012b), and reached a "historic height" (Feng, 2011:7). Poverty, which was believed already resolved by dramatic economic growth in the past, resurfaced as an acute socioeconomic problem in the post-financial crisis period. Aggravated by a surge in the youth unemployment rate (8\% in 2010) and a fast growing elderly population (12\% in 2013) (Cho et al., 2012), between 2000 and 2010 nearly $10 \%$ of the population was living in poverty (Kim et al., 2011), and in 2008 roughly $12 \%$ of the total labor force fell into the category of the "working poor" (Kang, 2012b). The poor class whose household income was below half of the average national income level—which refers to the "relative poverty" rate-had declined in number until 1992 but began to rebound after Kim Young Sam took office, and accelerated further after the financial crisis, reaching a peak of 14.4\% in 2007 (Yu, 2009). This high level of relative poverty not only exceeded the average in OECD countries (Organization for Economic Cooperation and Development [OECD], 2008), but its pace surpassed that of growing inequality (a Gini coefficient), which implies that poverty became a much more serious problem than increasing inequality (Yu, 2009).

Feng (2011:4) argues that the "worldwide capitalist expansion fueled by an unconstrained free-market ideology and the rise in power of multinational corporations" challenged and undermined the state and local authority. Amid the total economic chaos brought on by the financial crisis, the Kim Dae Jung administration and successive governments launched comprehensive welfare reform policies, but the underlying motivations for them were political considerations and international pressures. Fearing the failure of economic reforms due to weak social security networks in Korea, the IMF and the World Bank urgently requested that the government implement and strengthen social welfare systems (Kim et al., 2011; Shin, 2008). During the Kim Dae Jung, Roh Moo-hyun (2003-07), and Lee Myung-bak (2008-2012) administrations, spending on social welfare increased steadily: It "doubled in the five years after the crisis, increasing from 1.3 percent of the state budget in 1997 to 3.3 percent in 2001" (Kim et al., 2011:130). This growing rate was the highest among the member countries of the OECD that Korea joined in 1996. But government efforts to improve welfare fell short of global standards and expectations. In 2008, Korea spent only 8.3\% of GDP on public welfare, which was the lowest among OECD members (the average was 20.6\%) after Mexico (7.6\%) (Kang. 2012a). Even as state assistance to welfare grew, its contribution to poverty reduction, only $13.9 \%$ (the OECD average was 149\%), and to income distribution, merely 6.2\%, remained small (26\%-87\% in OECD countries) (Korea Institute for Health and Social Affairs [KIHASA], 2011).

It is exceedingly challenging for a democratizing government to perform well under neoliberal globalization (Chang, Chu, \& Park, 2007). Fukuyama (2011:87) asks "whether deep structural inequalities of the sort plaguing many developing democracies can even be solved through democratic means alone." Nevertheless, it is imperative for the government to provide to the public basic welfare security in order to prevent the still nascent democracy from faltering. The "productive welfare" policy pursued by the Kim Dae Jung administration and the "active welfare" slogan espoused by the Lee Myung-bak government were, however, equally deficient because both were primarily market-oriented and growth-focused. As the governments tried to improve social security by creating jobs and boosting economic growth - programs that simply replicated the authoritarian welfare system of the Park Chung Hee regime - the retired and the unemployed were left unprotected and inevitably relegated to the poor strata.

\section{Attachment to Egalitarianism and Conception of the Paternalistic State}

In comparison with other Western advanced democracies and contiguous democratizing countries in Asia, Korea stands out as a nation where people tend to have a strong sense of "substantive" (as opposed to "procedural") democracy and prioritize egalitarian welfare and communitarian security as a prime duty of a democratic regime or the state. When asked about the most essential property of a democratic system, 35.7\% of Koreans pointed to economic equality; they valued other democratic attributes at slightly lower level - popular election (35.4\%), protecting liberty (14.5\%), and economic security (10.1\%). Chu et al. (2009:145) lament that in Asia "democracy lost favor to economic development by a wide margin ... most would trade it for economic development." Yet Koreans' preference for economic equality over other democratic dimensions was far greater than that of their peers in democratized Japan (17.4\%) and democratizing Taiwan (18.5\%) (Shin, 2012). The stress on economic equality in assessing a democratic principle was clearly divided by socioeconomic status in Korea: on the procedural importance of democracy (e.g., elections and freedom), a majority of the highest income group (59\%) responded positively, whereas only $23 \%$ of people in the 
lowest income group did so (Shin, 2012). When asked about socioeconomic issues in a democracy in the pre- and post-financial crisis period, an overwhelming majority of Koreans expressed a preference for economic development over democratization (53.2\% versus $8.8 \%$ ) in 1997 , and the disparity grew in $1998(65.2 \%$ versus $7.8 \%)$ (Hong \& Cho, 2006). To recapitulate, Shin et al. (2003) found that $71 \%$ of Koreans approved of the ideals of democracy, while only $6 \%$ supported its procedural terms.

This means that most Koreans considered communitarian and egalitarian welfare a much more important democratic attribute than political freedom and individual civil liberty. In this respect, Shin (2012:264) suggests that to Koreans "democracy means government for the people more than it means government by the people" (emphasis added). This tendency contrasts starkly with traditions of liberal individualism and political pluralism in the West, where the number of Westerners who support the procedural aspects of democracy far outnumber those who support its ideals. Highly endorsed democratic values in the West are "social pluralism, the class system, the civil society, the belief in the rule of law, the experience with representative bodies, the separation of spiritual and temporal authority, and the commitment to individualism" (Huntington, 1997:6). Yet in Korea, a democratic system is more instrumental than intrinsic (Kang, 2010).

Where then does the preference for economic equality and security over political freedom and civil liberty that is deeply and widely entrenched in the mindset of ordinary Koreans come from? Karantnycky and Ackerman (2005) find that a typical elite-led (not civic-coalition led) mode of transition to democracy deterred Asians from nurturing individual liberty in the post-transition era. Fukuyama (2011) emphasizes that in an unequal social situation with an unleveled playing field, people were inclined to be less lenient toward growing inequality and tended to call for immediate and direct state intervention to rectify it. Huntington (1997) argues that the longevity of exposure to Western influences diversified people's receptivity to liberal political ideology.

Though all of the above explanations are plausible, I believe that the core of the deep-seated substantive conception of democracy among Koreans has historical and cultural origins. The devastating consequences of the Korean War (1950-53) and the following long period of economic destitution, together with the near annihilation of the landed class after a successful land reform promptly implemented after the establishment of the Republic of Korea in 1948, produced the unintended outcome of leveling the playing field, paradoxically rendering a majority of poverty-stricken and war-torn people highly "equal." In addition, Korea has been known as a paradigmatic case of a Confucian society in Asia (Park \& Shin, 2006). The often dubbed "Asian values" of Confucian Asia clearly differed from Western liberal, plural cultures in many respects. One distinctive feature of traditional Confucian values that remains strong among Koreans is egalitarianism. According to Shin's (2012) recent analysis, Koreans value egalitarianism much more than individualism (27.7\%), fatalism (5.3\%), and hierarchism (16.0\%). World Values Surveys in 2005-08 reveal that Koreans' adherence to egalitarianism $(51 \%)$ was higher than that of other Asians-Japan (41.0\%), Taiwan (31.4\%), China (30.1\%), and Vietnam (31.2\%). The strong attachment to egalitarianism in Korea originated from a communitarian and collectivist welfare tradition where harmony and cooperation among community members were stressed (Huntington, 1991b), collective welfare was accentuated over individual freedom, and communal responsibilities were given priority over personal rights (Park \& Shin, 2006).

Along with strong egalitarian and communitarian values, Koreans perceived the provision of welfare and security (rather than the protection of individual rights) as the primary role of polity (Huntington, 1997). Through observing authority and order and respecting hierarchy, Koreans came to consider a benevolent, paternalistic polity to be a model of good governance. With this paternalistic and moralistic view of the role of the state, they expected government to protect citizens suffering from economic hardship and to provide assistance that would prevent extreme poverty. A recent survey illustrates that Koreans' attachment to the principle of meritocracy (moral leadership) was higher (13.7\%) than that of the Japanese (3.4\%) and the Taiwanese $(2.5 \%)$. Also, a higher percentage of Koreans were attracted to the tenet of paternalism (parental benevolence) of the state than were their Japanese (5\%) and Taiwanese (12\%) peers. The survey also found that lower-income groups were more committed to paternalistic meritocracy than higher-income groups in Korea (Shin, 2012).

Koreans' attachment to egalitarian and communitarian values and preponderant preference for paternalistic governance made the objective consequences of government performance in recovering from an economic crisis and relieving income inequality deviate from people's subjective, perceived outcomes of government's supplies to public demands. An eminent theorist of democracy, Robert Dahl (1971:95), reminded us long ago: "Between a condition of objective inequality and the response of a disadvantaged person lie the perceptions, evaluations, and expectations-in short, the psyche-of the individual." Not only did the two dimensions diverge, but also the perception, evaluations, and expectations (rather than objective inequality) mattered more critically to democratic development. This is because depending on the target of people's externalization of social problems - in other words, to whom people attribute the main cause of current economic hardship and political corruption-democracy can wax and wane. In this respect, 
Kang's (2012b) recent findings are telling: Over 90\% of Koreans thought income differences were too large; $75 \%$ answered that it was the government's responsibility to reduce the wage gap; and $75 \%$ thought taxes on the wealthy were too low. The deeply embedded sense of a benevolent and paternalistic state among Koreans is also well reflected in other surveys: on the question of whether government should be responsible for providing appropriate living expenses to the unemployed, a higher percent of Koreans (3.7\%) replied positively than did those in Western advanced democracies-2.41\% in the U.S., 3.01\% in the U.K., 2.93\% in Germany, and 3.26\% in Sweden (Park, 2005).

\section{Critical of Dismal Government Performance and Distrustful of Democratic Legitimacy}

Scholars and other experts on democracy have begun to pay attention to cultural legitimacy as well as to institutional rule making and implementation, regarding both as pivotal preconditions for democratic consolidation (e.g., Diamond, 1999; Linz \& Stepan, 1996). The legitimation of a democratic regime by its citizens' consensus and their expression of satisfaction with its performance contribute to the durability of a nascent democracy. Declining democratic support and growing public discontent with government deficiencies do not always or instantly result in democratic rollback, just as economic prosperity does not always ensure democratic consolidation (Park, 2011). But, as Diamond (1999) correctly suggests, legitimation and satisfactory performance often furnish a favorable context in which democracy can survive and thrive. At the same time, disappointing government performance does not always lower democratic legitimacy or impede democratic consolidation; nonetheless, there exists "a reciprocal relationship between legitimacy and performance" (Diamond, 1999:77). The legitimacy and sustainability of a democratic regime are contingent on its performance (Anderson \& Guillory, 1997; Bratton \& Mattes, 2001; Weatherford, 1984).

Koreans nowadays, especially after the financial crisis, remain committed to democracy in principle but disenchanted with it in practice. Shin and his colleagues (2003) found that an absolute majority of Koreans (92\%) believed democracy was desirable for Korea and a large majority (74\%) considered it suitable. But fewer than half expressed unconditional support for democracy. When asked whether "democracy is always preferable to any other kind of government," a lower percentage (47.9\%) answered affirmatively than did Japanese (70.4\%) and Taiwanese (50.9\%). Thus, Shin (2011:28) concludes that "the legitimacy of Korean democracy is wide in breadth but shallow in depth . . . is more superficial than profound, and more passive than active." By contrast, on the issue of citizens' perception of democratic performance, different stories are told. Kang (2012b) found that between Asian Barometer Survey I (2001-03) and Survey II (2005-08), Koreans' belief in democratic efficacy dropped from $72 \%$ to 55\%; the second largest decline among Asian democratizing countries after Thailand (24\%). His data also showed that Koreans' support for democracy decreased from $61 \%$ to $48 \%$ over the same period, the second lowest among those countries next to the Philippines (38\%).

In the literature on democratic performance, some have argued that political rather than economic performance is more closely correlated with democratic support (Bratton \& Mattes, 2001; Evans \& Whitefield, 1995; Rose, Mishler, \& Haerpfer, 1998; Rose, Shin, \& Munro, 1999; cf. Mishler \& Rose, 1997). Empirical evidence and theoretical argument sometimes affirm that poor economic performance does not always lead to a crisis of democratic legitimacy and to a decline in democratic support as was shown in some Eastern European democracies (Dalton, 2004; Kaufman, 2009; Vassilev, 2004). In the literature, the concept of "critical democrats" is introduced to refer to those who are strong advocates of democracy in principle but are highly disappointed with its performance in practice (Norris, 1999). According this view, the presence of critical democrats, far from being detrimental, is in fact advantageous to democratic development. First, disillusionment with performance deficit does not lead to regime crisis because "failure is blamed on the incumbents instead of system, and the ouster and replacement of the incumbents help to renew the system" (Huntington, 1991b:27). Second, the presence of critical democrats is an indicator of the high quality of the democratic regime and also often functions as a "healthy dose" of political skepticism: when elected officials are criticized for their poor performance that does not live up to public expectations, they tend to pursue reforms. Thus, it is not citizens' unqualified commitment to democratic ideas but reproach voiced by critical democrats that prompts democratic advancement (Qi \& Shin, 2011). Interestingly, then, the incongruence, rather than equilibrium, between ardent faith in democratic principles and low satisfaction with democratic performance provides the optimal condition for democratic consolidation. According to Park's (2011) estimate, about 35\% of Koreans were critical democrats.

The judgment that critical democrats could facilitate democracy was predicated on empirically verified evidence often found in advanced Western democracies. The scenario that disenchanted supporters of democracy could create in Korea might deviate from Western cases. In Korea, instead of fostering democracy by mounting pressure on the democratic government for better performance, the disgruntled may withdraw their support for democracy, be dissuaded from actively participating in politics, and even romanticize an authoritarian economic heyday, hence unwittingly reverting to an authoritarian mode of government performance. This unfortunate outcome, to democrats' dismay, has begun to be a reality. 


\section{Nostalgia for an Authoritarian Era}

In a series of national surveys conducted by major newspapers and research institutes, Park Chung Hee was repeatedly selected as the most popular and revered former political leader, far ahead of other former presidents, reaching a favorability level of 55.4\% in 2006 (Kang, 2010). As is well known, under the Park regime, Korea achieved impressive economic growth only at the expense of suffocating political repression through the exercise of ruthless and draconian dictatorial power. The former president's popularity was higher among older respondents than among the younger generations. His favorability soared to $65.5 \%$ in 2012 when both the general election and the presidential election produced breathtaking victories by the ruling conservative party. Park was chosen as the president who presided over the best government performance (51.1\%), rating twice as high as that for the late Kim Dae Jung (19.1\%). Park was preferred by the lower classes as well as the upper classes; in particular, his popularity among the lowest income group, whose monthly household income fell short of 1 million won (78.2\%), exceeded that among the richest group, with monthly household income over 7 million won (63.1\%) (Kim, 2013).

The so-called "Park Chung Hee syndrome" began to surge after the financial crisis, and the person who reaped the largest benefit from this phenomenon was his daughter Park Geun-hye, who was elected president in December 2012. In the aftermath of the financial crisis, she suddenly became one of the most influential political leaders, with strong public support. Kang (2012c:4) wrote that her popularity seemed to reify Park Chung Hee "as an image of the incarnation of modernization and of a leader of national restoration who saved Koreans from poverty." People seemed to believe that Park's "visible" hand in making and implementing effective policies boosted the economy, and that its growth relied primarily on his adroit political leadership - rather than on any other historical heritage or the auspicious international environment - that was "a fundamentally political artifact, historically created, maintained, and driven by Park Chung Hee" (Kim, 2011:10).

The economic "failure" of the democratic regime after the financial crisis begot nostalgia for the authoritarian regime. Koreans frustrated with poor government performance fondly recalled the legacy of authoritarian "success" in economic growth. The longing for authoritarianism is also prompted by economic successes in neighboring non-democratic Asian countries such as Singapore and Malaysia, and in particular, by China's economic adaptability and resilience in the face of a complex and rapidly globalizing world economy (Chang, Chu, \& Huang, 2006). As a consequence, though a majority of Koreans still prefer the democratic regime to an authoritarian polity (Shin, 2012), the growing nostalgia for authoritarianism is a sign that democratic legitimacy has stagnated and even eroded (Chang et al., 2007). Lingering authoritarian nostalgia could easily turn discontented citizens into "distrustful non-democrats"- whose tolerance of less democracy for the sake of economic recovery could threaten democratic stability - rather than into "critical citizens": Park (2011) found that the former (40\%) outnumbered the latter (35\%) in Korea. What Shin et al. (2003) referred to as "cognitive dissonance"-which in this case means the simultaneous existence or even growth of contradictory proclivities among citizens - manifested itself as the adoption of a democratic principle that did not always accompany the rejection of an authoritarian process of government performance (Shin, 2012). The ominous signs of the concomitant presence of an incomplete devotion to democracy due to distressing democratic performance with only a partial detachment from authoritarianism have begun to loom large, and have the potential to undermine democratic consolidation in Korea. Increasing political apathy and cynicism are represented by steadily declining voter turnout in major elections - local, parliamentary, and presidential—since the beginning of democratization in 1987 (Kim, 2005). More worrisome is the recent trend toward political conservatism among the lower class and the elderly.

After the restoration of democracy in 1987, the voting pattern in major elections was split by region. Three eminent political leaders divided the southern peninsula and exercised imperialistic power in each region-Kim Jong Pil in Ch'ungch'ŏng province, Kim Young Sam in Kyŏngsang province, and Kim Dae Jung in Ch'olla province. When the so-called "Three Kims" era ended, ideological and generational (or age) factors, along with regional division, began to distinguish a voting trend (Sŏ, 2013). Notably, the voting pattern defied the categorization by class. Yet the situation has begun to change in recent years in an ironic way deviating from a Western paradigm.

As expected, the upper classes were passionate advocates of conservative political parties and their candidates and held strong ideological attachment to conservatism, whereas the middle class was more geared toward progressive ideology and reformist political propensity. What was quite exceptional was the tendency for the lower class to be exceedingly conservative, an attitude that has become more apparent and stronger in recent elections. In the presidential election of 2002, the conservative party candidate received 34.3\% support from the lower class while his reformist opponent garnered 49\%. But 10 years later, in the 2012 presidential election, 52.4\% of the lower classes supported the conservative party leader while only $37.3 \%$ voted for the progressive candidate. Although the middle class still favored the progressive politician over the conservative one, the support gap shrank by half in 10 years (Sŏ, 2013). 
In the presidential election in 2012, conservative and progressive party candidates were equally focused on the issues of resolving social polarization and reducing the socioeconomic disparity between classes. Their public pledges on those topics reflected the widely shared public views on the urgency of these agendas. Compared to the middle and upper classes, the lower class was deemed to be more sensitive to welfare issues and more disadvantaged by economic poverty and social polarization, and therefore more likely to lean toward progressive political parties. Contrary to this normative expectation and class voting theory, the lower and lower middle classes as well as the upper class in fact cast a majority vote for Park Chung Hee's daughter, Park Geun-hye, and elected her as a president. The lower-class voters with a monthly household income below 2 million won supported her by an overwhelming majority of $65.7 \%$ versus $34.3 \%$ for the progressive opposition party candidate. The gap of $31.4 \%$ proved to be more than twice as great as that among the upper class with monthly household income over 7 million won-of those, $57.4 \%$ voted for the conservative and $42.6 \%$ for the progressive (a 14.8\% margin) (Kang, 2013). This implies that, though equally supportive, the lower class was more fervent adherents of conservative politics than the upper. The relationship between conservative voting and income level, while never linear in Korea, recently became more conspicuously U-shaped (Sŏ, 2013).

It is a great historical paradox and remains a puzzling enigma in the field of democratization and civil society in Korea that the working or lower class - which contributed most to remarkable economic growth, was oppressed most by the ironfisted dictatorship, contributed significantly to toppling the longtime authoritarian regime in the democratization movement of the 1970s and the 1980s, and further assisted democratic progress after the authoritarian fall—has begun to glamorize the autocratic leaders of the past. Working-class people suffered from authoritarian tyranny in the past and rose up against it; but now they are missing Park and fulfilled their longing for him by electing his daughter as national ruler. After becoming victims of the financial crisis and the ensuing neoliberal economic reforms that further aggravated their living conditions and destabilized their employment status, the working class became enthusiastic cheerleaders for conservative political parties and their candidates, despite the latter's largely lukewarm attitudes towards the issues of social security and economic equality. As E. H. Carr (1961:104-05) commented, it is ironic that in historical progress "[t]hose who pay the cost [contributors to democracy] are rarely those who reap the benefits [champions of democracy]." More ironic is the fact that this disparity in Korea happened not by chance but by choice. Karl Marx's most quoted dictum, that history repeats itself, first as tragedy and then as farce (in the $18^{\text {th }}$ Brumaire of Louis Bonaparte published in 1852), is reminiscent of the two historic events in Korea: the unconstitutional assumption of authoritarian power through the military coup of Park Chung Hee in 1961 and the constitutional ascendancy to democratic presidency by plebiscite of Park Geun-hye in 2012.

\section{In Lieu of Conclusion: Korean Democracy at a Crossroads}

Economic prosperity and equitable economic distribution under authoritarian political repression began to be upended in Korea in 1987: democratic freedom replaced autarchy with a gradual economic slowdown and widening inequality. The economy after the financial crisis in 1997 further increased poverty and job insecurity, and the majority of the middle class experienced downward mobility. Subsequent neoliberal globalization in earnest was not so much a friend as a foe of democracy. Post-crisis government welfare reform policies were too cumbersome to prevent worsening poverty and polarization, and an increasing share of the lower class was left unprotected and remained social outcasts. The inability of the democratic regime to deal with the economic recession and the financial crisis raised the level of public discontent with the democratic government's performance enough to attenuate public support for democracy. Dwindling democratic legitimacy obviously imperiled democratic consolidation and sustainability. Though still devoted to democracy in principle, Koreans were deeply disillusioned with democracy in practice and worryingly attracted to a non-democratic mode of governance.

The prevalent dissatisfaction of the public with the government's performance was augmented by persistent and deeply embedded Confucian values. The emphasis on egalitarian and communitarian virtues in Confucianism led most Koreans to conceive of democracy as prioritizing economic equality and security; they outnumbered those who were attached to the procedural merits of political freedom and individual rights. Rampant belief in the benevolent, paternalistic role of the state led them to consider relief from poverty and economic hardship as the prime moral and obligatory duty of the state and deem it imperative for the state to intervene to fulfill this normative responsibility. Thus, they tended to attribute the socioeconomic predicaments they suffered to government failures. Rising disgruntlement of the public generated authoritarian nostalgia for the "good old days" of Park Chung Hee's leadership.

The coexistence and parallel adoption of democratic principles and of attraction to authoritarian practice not only slowed democratic consolidation but also marred democratic legitimacy. The conservative trend appeared most conspicuously among those who were the most poverty-stricken - the working class. It is a historical irony that the working class, the staunch advocates of democracy in the past, now renounced progressive democratic politicians, most of whom had been their comrades in the fight for freedom under authoritarian rule. Instead, the working class, the 
former freedom fighters, becomes the zealots most receptive to conservative leaders in the present, most of whom are the offspring of authoritarian rulers.

Hegel noted that the owl of Minerva spreads its wings to fly only when dusk begins to fall. Is it possible that this condition will apply to the trajectory of Korean democratic development? Trustworthy democrats in ideal, but distrustful non-democrats in reality ... (Note 1)

\section{References}

Anderson, C. J., \& Guillory, C. A. (1997). Political institutions and satisfaction with democracy: A cross-national analysis of consensus and majoritarian systems. The American Political Science Review, 91(1), 66-81.

Bratton, M., \& Mattes, R. (2001). Support for democracy in Africa: Intrinsic or instrumental? British Journal of Political Science, 31(3), 447-474.

Carr, E. H. (1961). What is history? New York, NY: Vintage Books.

Chang, Y., Chu, Y., \& Huang, M. (2006). The uneven growth of democratic legitimacy in East Asia. International Journal of Public Opinion Research, 18(2), 246-255.

Chang, Y., Chu, Y., \& Park, C. (2007). Authoritarian nostalgia in Asia. Journal of Democracy, 18(3), 66-80.

Cho, C., Pak, C., \& Kang, C. (2012). Han'gukŭi kyŏngjesŏngjanggwa sahoejip'yoŭi pyŏnhwa. [Economic development and change in social indicators in Korea]. Kümyung gyŏngje yŏn'gu [Financial Economic Research], 470.

Chu, Y., Bratton, M., Lagos, M., Shastri, S., \& Tessler, M. (2008). Public opinion and democratic legitimacy. Journal of Democracy, 19(2), 74-87.

Chu, Y., Diamond, L., Nathan, A., \& Shin, D. C. (2009). Asia's challenged democracies. The Washington Quarterly, 32(1), 143-157.

Dahl, R. A. (1971). Polyarchy: Participation and opposition. New Haven: Yale University Press.

Dalton, R. J. (2004). Democratic challenges, democratic choices: The erosion of political support in advanced industrial democracies. Oxford: Oxford University Press.

Diamond, L. (1999). Developing democracy: Toward consolidation. Baltimore: Johns Hopkins University Press.

Evans, G., \& Whitefield, S. (1995). The politics and economics of democratic commitment: Support for democracy in transition societies. British Journal of Political Science, 25(4), 485-514.

Feng, W. (2011). The end of 'growth with equity'? Economic growth and income inequality in East Asia." Asia Pacific Issues, 101. Honolulu: East-West Center.

Fukuyama, F. (2011). Dealing with inequality. Journal of Democracy, 22(3), 79-89.

Hahm, C. (2008). South Korea's miraculous democracy. Journal of Democracy, 19(3), 128-142.

Hong, J., \& Cho, S. (2006). Kyŏngje wigiwa minjujuŭi: oehwanwigi chŏnhu taejungŭi minjujuŭich'eje chijiŭi pyŏnhwa. [Economic crisis and democracy: Change in public support for a democracy system in pre- and post-financial crisis]. Sinroeyŏn'gu [Trust Research], 16(1-2), 109-136.

Houle, C. (2009). Inequality and democracy: Why inequality harms consolidation but does not affect democratization. World Politics, 61(4), 589-622.

Huber, E., \& Solt, F. (2004). Successes and failures of neoliberalism. Latin American Research Review, 39(3), 150-164.

Huntington, S. P. (1991a). The third wave: Democratization in the late twentieth century. Norman: University of Oklahoma Press.

Huntington, S. P. (1991b). Democracy's third wave. Journal of Democracy, 2(2), 12-34.

Huntington, S. P. (1997). After twenty years: The future of the third wave. Journal of Democracy, 8(4), 3-12.

Im, H. (2011). Better democracy, better economic growth? South Korea. International Political Science Review, 32(5), 579-597.

Kang, W. (2012a.) Han'guk minjujuŭiesŏ kyŏngjejŏk pulp'yŏngdŭnge taehan insikŭi chŏngch'ijŏk hyogwa: minjujuŭi hyonŭngsŏnge taehan hyogwarŭl chungsimŭro. [The political consequence of citizens' perceptions of economic inequality in Korea: Focusing on its effect on the efficacy of democracy] Han'gukkwa kukchejŏngch'I, 28(2), $145-175$.

Kang, W. (2012b). Inequality, welfare system, and satisfaction with democracy in Korean democracy (Unpublished manuscript). 
Kang, W. (2012c). Democratic performance and authoritarian nostalgia in Korean democracy (Unpublished manuscript).

Kang, W. T. (2010). Missing the dictator in a new democracy: Analyzing the "Park Chung Hee syndrome" in South Korea. Political and Military Sociology, 38(1), 1-25.

Kang, W. T. (2013). 2012daesŏnesŏ nat'anan han'gukchŏngchi'iŭi t' ŭksŏnggwa pyŏnhwa [2012 presidential election and features and changes of Korean politics] (Unpublished manuscript).

Karantnycky, A., \& Ackerman, P. (2005). How freedom is won: From civil resistance to durable democracy. New York: Freedom House.

Kaufman, R. R. (2009). The political effects of inequality in Latin America: Some inconvenient facts. Comparative Politics, 41(3), 359-379.

Kim, B. (2011). Introduction: The case for political history. In B. Kim \& E. Vogel (Eds.), The Park Chung Hee era: The transformation of South Korea, 1-31. Cambridge: Harvard University Press.

Kim, J. (2005). "Bowling together" isn't a cure-all: The relationship between social capital and political trust in South Korea. International Political Science Review, 26(2), 193-213.

Kim, L. (2013). Wae chŏsodŭgch'ŭngŭn saenŭridangul chijihanŭnga? Che19dae ch'ongsŏnul t'onghae pon han'guk chŏsodügch 'úng yugwŏnjaŭi t'up'yphŏngt'ae" [Why does the lower-income group support the saenuri party? The voting behavior of Korea's lower income group in the $19^{\text {th }}$ general election] (Unpublished master's thesis). Korea University, Seoul, South Korea.

Kim, S. (2006). Pulp'yŏngdŭnggwa han'gukŭi minjujuŭi [Inequality and democracy in Korea]. Aseayŏn'gu, 49(4), 37-67.

Kim, T., Kwon, H., Lee, J., \& Yi, I. (2011). "Mixed governance" and welfare in South Korea. Journal of Democracy, 22(3), 120-134.

Koo, H. (2001). Korean workers: The culture and politics of class formation. Ithaca: Cornell University Press.

Korea Institute for Health and Social Affairs (KIHASA). (2011). Pogŏn, Pokchi Issue \& Focus, 94.

Kuznets, S. (1955). Economic growth and income inequality. The American Economic Review, 45(1), 1-28.

Linz, J. J., \& Stepan, A. (1996). Toward consolidated democracies. Journal of Democracy, 7(2), 14-33.

Mishler, W., \& Rose, R. (1997). Trust, distrust and skepticism: Popular evaluations of civil and political institutions in post-communist societies. The Journal of Politics, 59(2), 418-451.

Norris, P. (Ed.). (1999). Critical citizens: Global support for democratic governance. Oxford: Oxford University Press.

Organization for Economic Cooperation and Development (OECD). (2008). Growing Unequal. France: OECD.

Pak, S. (2005). Sŏngjanggwa punbaee taehan kukminŭisik sŏlmunjosa kyŏlgwa [National survey on growth and income distribution policy]. Pogŏnbokjip'orŏm [Health and Welfare Policy Forum], February, 26-38.

Park, C. (2011). Political discontent in South Korea. International Review of Sociology, 21(2), 391-412.

Park, C., \& Shin, D. C. (2006). Do Asian values deter popular support for democracy in South Korea? Asian Survey, 46(3), 3413-61.

Qi, L., \& Shin, D. C. (2011). How mass political attitudes affect democratization: Exploring the facilitating role critical democrats play in the process. International Political Science Review, 32, 245-262.

Rose, R., Mishler, W., \& Haerpfer, C. (1998). Democracy and its alternatives: Understanding post-communist societies. Baltimore: The Johns Hopkins University Press.

Rose, R., Shin, D. C., \& Munro, N. (1999). Tensions between the democratic ideal and reality: South Korea. In P. Norris (Ed.), Critical citizens: Global support for democratic government , 146-165. Oxford: Oxford University.

Shin, D. C. (2011). Is democracy the only political game worth playing in Korea? Exploring citizen attitudes toward democratic legitimacy (Paper presented at Workshop on East Asian Perspectives on Political Legitimacy) (18-20 August).

Shin, D. C. (2012). Confucianism and democratization in East Asia. New York: Cambridge University Press.

Shin, D., C., Park, C., Hwang, A., Lee, H., \& Jang, J. (2003). The democratization of mass political orientations in South Korea: Ascertaining the cultural dimension of democratic consolidation. International Journal of Public Opinion Research, 15(3), 265-284. 
Shin, K. (2008). Hyŏndae han'guk pulp’yŏngdŭng kujoŭi pyŏnghwa: minjuhwa, segyehwawa saeroun sahoejŏk wihŏm [Changing inequality in contemporary Korea: Democratization, globalization, and new social risks]. Hyŏndae sahoewa munhwa, 27, 5-33.

Sŏ, P. (2013). Sahoegyunyŏlgwa chŏngdangjŏngch'i [Social cleavages and party politics: Comparison between the $16^{\text {th }}$ and $18^{\text {th }}$ presidential elections] (Unpublished manuscript).

Suh, D. (2013). Challenges to democracy in Korea. In R. Youngs (Ed.), A new context for EU-Korean relations , 69-80. Madrid: FRIDE.

Tilly, C. (2007). Democracy. New York: Cambridge University Press.

Vassilev, R. (2004). Economic performance and regime legitimacy in post-communist Bulgaria. Politics, 24(2), 113-121.

Weatherford, M. S. (1987) How does government performance influence political support? Political Behavior, 9(1), $5-28$.

Weyland, K. (2004). Neoliberalism and democracy in Latin America: A mixed record. Latin American Politics and Society, 46(1), 135-157.

Yu, K. (2009). Urinara pingonbyŏnhwa ch'uiwa yoin punsŏk [The poverty trend and its causes in Korea]. KDIchŏngch'aekp'orŏm, 215, 1-13.

\section{Notes}

Note 1. A part of an earlier version of this paper appeared in Suh (2013).

\section{$(c)$ EY}

This work is licensed under a Creative Commons Attribution 3.0 License. 